\title{
Characterization and classification of Rare Disease Registries by using exploratory data analyses
}

\author{
Alessio $\mathrm{Coi}^{1,2^{*}+}$, Michele Santoro ${ }^{2 \dagger}$, Michele Lipucci ${ }^{3}$, Anna Maria Bianucci $^{4}$, Sabina Gainotti ${ }^{5}$, Emanuela Mollo ${ }^{5}$, \\ Luciano Vittozzi ${ }^{5}$, Domenica Taruscio ${ }^{5}$, Fabrizio Bianchi ${ }^{1,2}$
}

From 7th European Conference on Rare Diseases and Orphan Products (ECRD 2014)

European Commission and Patients Associations identify Registries as strategic instruments to improve knowledge in the field of Rare Diseases [1,2]. Interoperability between Rare Diseases Patient Registries (RDPR) is especially needed to support research activities, to validate therapeutic treatments and to plan public health actions. Because of the extreme variety of RDPR, a uniform and standardized way of collecting data and the identification of specific levels of connection between RDPR with similar aims is needed.

In this study, exploratory data analyses were applied to the EPIRARE (European Platform for Rare Diseases Registries) Registry Survey in order to generate a macroclassification and characterization of RDPR and to deepen different informative needs.

At first, a Multiple Correspondence Analysis (MCA) suggested associations between selected variables characterizing the structure of RDPR (Figure 1). Then, a Cluster analysis (CA) was developed using the declared "Aims" of each RDPR. CA confirmed the variable associations emerged by MCA and identified three groups defined as: Public Health (PHR), Clinical-Genetic Research (CGRR), and Treatment Registries (TR). Finally, the random forest (RF) method was applied to the Survey data, leading to six classification models endowed of good predictive power and thus confirming the reliability of considering three groups of RDPR. RF also identified several informative variables which allowed the characterization of the three categories of RDPR, defined by data of different nature and by different levels of diffusion (Table 1).

These results, identifying different profiles of RDPR and specific informative needs, represent an informative support aimed at addressing the activities for the design

\footnotetext{
* Correspondence: alessio.coi@ifc.cnr.it

+ Contributed equally

${ }^{1}$ Fondazione Toscana Gabriele Monasterio, Pisa, Italy

Full list of author information is available at the end of the article
}

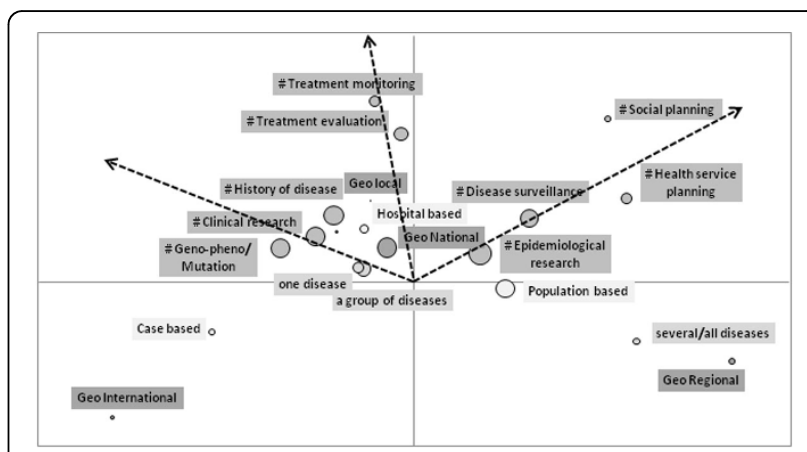

Figure 1 Factorial plan by MCA.

of an European platform of Rare Diseases. Identification of informative cores could address the activities of a platform able to enhance the sharing of information between RDPR with common aims, but also to facilitate a coherent dialogue between RDPR with different profiles.

Guide to interpretation: the arrows indicate the directions of association among the aims; the dimension of the circles represents the frequency of the variable. The higher are the coordinate and the frequency of the variable, the more it contributes to the interpretation of the factorial axis; variables placed on the same direction are correlated.

\footnotetext{
Acknowledgements

This work is part of the activities of EPIRARE, a 3-year project started on April 15, 2011 (grant 201012 02) and co-funded by the European Commission within the EU Programme on Health.

\section{Authors' details}

${ }^{1}$ Fondazione Toscana Gabriele Monasterio, Pisa, Italy. ${ }^{2}$ Institute of Clinical Physiology, National Council of Research, Pisa, Italy. ${ }^{3}$ European Organisation for Rare Diseases (EURORDIS), Paris, France. ${ }^{4}$ Department of Pharmacy, University of Pisa, Italy. ${ }^{5}$ National Centre for Rare Diseases, National Institute for Health, Rome, Italy.
} 
Table 1 Main characteristics of Clinical-Genetic Research, Treatment, and Public Health Registries according to the most informative variables emerged after the random forest method. Variables reported in the table characterize most of the registries of each class.

\begin{tabular}{|c|c|c|c|}
\hline Variables & Public Health Registries & Treatment Registries & $\begin{array}{l}\text { Clinical-Genetic research } \\
\text { Registries }\end{array}$ \\
\hline Aims & $\begin{array}{l}\text { - epidemiologic research } \\
\text { - disease surveillance } \\
\text { - healthcare services } \\
\text { planning }\end{array}$ & $\begin{array}{l}\text { - treatment evaluation } \\
\text { - treatment monitoring }\end{array}$ & $\begin{array}{l}\text { - clinical research } \\
\text { - genetic } \\
\text {-natural history of the disease }\end{array}$ \\
\hline Collected data & socio-demographic & $\begin{array}{l}\text { - clinical } \\
\text { - medications, devices and health services } \\
\text { - genetic } \\
\text { - family history } \\
\text { - date of the patient death } \\
\text { - patient-reported outcomes - anthropometric } \\
\text { info }\end{array}$ & $\begin{array}{l}\text { - clinical } \\
\text { - genetic } \\
\text { - family history }\end{array}$ \\
\hline Coding system & $\mathrm{ICD}$ & No coding system or own code & No coding system or own code \\
\hline $\begin{array}{l}\text { Services requested to a EU } \\
\text { platform }\end{array}$ & "Quality control systems" & "Facilitated access to useful data sources" & "Model documents" \\
\hline
\end{tabular}

Published: 11 November 2014

\section{References}

1. Commission of the European Communities: Communication from the Commission to the European Parliament, the Council, the European Economic and Social Committee and the Committee of the Regions on Rare Diseases: Europe's challenges. Brussels; 2008, COM(2008) 679 final. Available at: http://ec.europa.eu/health/ph_threats/non_com/docs/ rare_com_en.pdf.

2. Council recommendation of 8 June 2009 on an action in the field of rare diseases. Official Journal of the European Union, 2009/C 151/02. Available at:http://eurlex.europa.eu/LexUriServ/LexUriServ.do?uri=OJ: C:2009:151:0007:0010:EN:PDF.

doi:10.1186/1750-1172-9-S1-P4

Cite this article as: Coi et al:: Characterization and classification of Rare Disease Registries by using exploratory data analyses. Orphanet Journal of Rare Diseases 2014 9(Suppl 1):P4.

Submit your next manuscript to BioMed Central and take full advantage of:

- Convenient online submission

- Thorough peer review

- No space constraints or color figure charges

- Immediate publication on acceptance

- Inclusion in PubMed, CAS, Scopus and Google Scholar

- Research which is freely available for redistribution

Submit your manuscript at www.biomedcentral.com/submit
C Biomed Central 